\title{
The Impact of COVID-19 and "Emergency Remote Teaching" on the UK Computer Science Education Community
}

\author{
Tom Crick \\ Swansea University \\ Swansea, UK \\ thomas.crick@swansea.ac.uk \\ Richard Watermeyer \\ University of Bristol \\ Bristol, UK \\ richard.watermeyer@bristol.ac.uk
}

\author{
Cathryn Knight \\ Swansea University \\ Swansea, UK \\ cathryn.knight@swansea.ac.uk \\ Janet Goodall \\ Swansea University \\ Swansea, UK \\ j.s.goodall@swansea.ac.uk
}

\begin{abstract}
The COVID-19 pandemic has imposed "emergency remote teaching" across education globally, leading to the closure of institutions across a variety of settings, from early-years through to higher education. This paper looks specifically at the impact of these changes to those teaching the discipline of computer science in the UK. Drawing on the quantitative and qualitative findings from a largescale survey of the educational workforce $(\mathrm{N}=2,197)$ conducted in the immediate aftermath of institutional closures in March 2020 and the shift to online delivery, we report how those teaching computer science in various UK settings $(n=214)$ show significantly more positive attitudes towards the move to online learning, teaching and assessment than those working in other disciplines; these perceptions were consistent across schools, colleges and higher education institutions. However, whilst practitioners noted the opportunities of these changes for their respective sector - especially a renewed focus on the importance of digital skills - they raised a number of generalisable concerns on the impact of this shift to online on their roles, their institutions and their sectors as a whole; for example, the impact on workload, effective pedagogy and job fragility. More specifically for computer science practitioners, curricula and qualifications, there were concerns raised regarding the ability to meaningfully deliver certain core topics such as mathematical foundations and programming, as well as the impact on various types of formal examinations and assessment. Based on the data obtained from this rapid response survey, we offer informed commentary, evaluation and recommendations for emerging learning and teaching policy and practice in the UK computer science community as we move into the 2020-2021 academic year and beyond.
\end{abstract}

\footnotetext{
Permission to make digital or hard copies of all or part of this work for personal or classroom use is granted without fee provided that copies are not made or distributed for profit or commercial advantage and that copies bear this notice and the full citation on the first page. Copyrights for components of this work owned by others than ACM must be honored. Abstracting with credit is permitted. To copy otherwise, or republish, to post on servers or to redistribute to lists, requires prior specific permission and/or a fee. Request permissions from permissions@acm.org.

UKICER '20, September 3-4, 2020, Glasgow, United Kingdom

(C) 2020 Association for Computing Machinery.

ACM ISBN 978-1-4503-8849-8/20/09 . \$ $\$ 15.00$

https://doi.org/10.1145/3416465.3416472
}

\section{CCS CONCEPTS}

- Social and professional topics $\rightarrow$ Computing education; User characteristics; - General and reference $\rightarrow$ Empirical studies.

\section{KEYWORDS}

COVID-19, emergency remote teaching, practitioner perceptions, pedagogy, assessment, curriculum, computer science education

ACM Reference Format:

Tom Crick, Cathryn Knight, Richard Watermeyer, and Janet Goodall. 2020. The Impact of COVID-19 and "Emergency Remote Teaching" on the UK Computer Science Education Community. In United Kingdom \& Ireland Computing Education Research conference. (UKICER '20), September 3-4, 2020, Glasgow, United Kingdom. ACM, New York, NY, USA, 7 pages. https: //doi.org/10.1145/3416465.3416472

\section{INTRODUCTION}

\subsection{The Impact of COVID-19}

The impact of the COVID-19 (SARS-CoV-2) global pandemic is currently incalculable; it has affected, and continues to affect, profound social suffering, significant cultural disruption, and deep economic hardship. While indiscriminate in terms of whom it infects, it has largely punished society's most vulnerable and less fortunate [43, 47, 48]; worse now, it appears that the virus may have to be tolerated on an indefinite basis [27].

The impact of the pandemic on the wider education system, across all settings, has been profound $[1,46]$, presenting significant challenges for learning, teaching and assessment (LT\&A), especially from a pedagogic perspective [20, 24, 39] - and how face-to-face learning is somehow perceived to be "better value" than online approaches $[10,36]$. In the United Kingdom (UK), there have been major responses from governments, organisations and institutions at all levels and settings; from major national policy initiatives to support learners and maintain quality and standards across all settings, to ongoing government inquiries on the longer-term impact of COVID-19 on education and children's services.

\subsection{Educational Technology and Digital Learning}

The general impact and efficacy of educational technology and digital learning is still uncertain in the formal academic literature, 
being dependent on specific educational settings and LT\&A context. Whilst a range of international research studies have shown benefits of the successful application of digital LT\&A across a variety of contexts and settings, the widespread adoption, implementation and evaluation of educational technologies has yet to be fully realised $[9,28-30]$. The research and policy debate regarding the efficacy, utility and impact of educational technology and digital practice is ongoing, reinforced by a national digital learning and teaching strategy in Scotland [41], a new Digital Competence Framework for all learners aged 3-16 in Wales [2, 50], a new national strategy for schools in England [19], as well as recent work from Jisc (a not-for-profit organisation that provides digital solutions for UK education and research) on digital practice in further education (FE) and higher education (HE) [26], and from the UK's Quality Assurance Agency on a taxonomy for digital learning [38]. We have also seen updated guidance on how digital learning can support learning, as well as a rapid evidence assessment on remote learning from the Education Endowment Foundation [22, 23].

\subsection{The Discipline of Computer Science}

It is clear that the academic discipline of computer science - and indeed the wider information technology sector - has much to offer to address the wider challenges resulting from the COVID-19 pandemic; from computational modelling, the use of AI, machine learning and big data, as well as the wider legal, social, ethical and professional issues, such as from contact tracing, personal data sharing/storage, and the use of image recognition and surveillance $[6-8,21,44]$. There has also been recent analysis on the impact of COVID-19 on the computer science research community - as we have seen across international scientific research communities more broadly [35] - especially on ongoing projects, careers, and dissemination of work [31]. However, there has been little focus on what this means for computer science education and practitioners, especially thinking about the range of specific disciplinary challenges for LT\&A, across all settings and levels. This directly links to recent significant changes to computer science curricula, qualifications and practice across the UK [4,11, 18, 34], as well as the emerging focus on the required digital skills and infrastructure to support the UK's post-COVID economic renewal [14, 17, 45].

\subsection{Motivation}

We thus undertook a survey of UK computer scientists on their perspectives as practitioners on the rapid shift to "emergency remote teaching" and transitioning online at the height of the COVID-19 crisis, and what they identify and forecast as its immediate and prospective impacts. The data was collected in the immediate aftermath of the forced institutional lockdowns and shift to online LT\&A. It aimed to provide insight into emerging policy and practice; impact on practitioners, institutions and thus students; how might this change the discipline as a result; and what might this mean for the coming academic year and the longer-term. The discussion that follows is based upon the perspectives of $n=214$ practitioners (as part of a larger survey of the educational workforce $(\mathrm{N}=2,197)$, including specific work on the UK higher education sector in the UK [49]) drawn from across all educational settings, institutions, and the career hierarchy, and what they recognise to be the major consequences of COVID-19, the transition to online LT\&A, and the challenges of maintaining "continuity of learning". Their accounts document the hopes and fears of the UK computer science education community in the face of seismic and, as may prove to be, inalterable shifts. The majority of respondents tend towards a significantly more positive view of online migration than those working in other disciplines, recognising the opportunities and potential affordances of the crisis; these perceptions were consistent across all educational settings. There were some, albeit a minority, who raised a number of generalisable concerns on the impact of this shift to online and the challenges relating to their roles, their institutions and their sectors as a whole.

A Note on Terminology. While in many instances throughout this paper we will refer to the UK - consisting of the four nations of England, Scotland, Wales and Northern Ireland - we will attempt to be as clear as possible when referring to specific policies or initiatives across or between the nations, as a number of policy areas, including education and skills, are devolved to the respective national governments. However, for the purposes of this study, we will be looking at aggregated UK-level impacts and perceptions of computer science practitioners.

With regards to the consistent naming of the discipline through this paper, we use "computer science" to refer to the wider cognate discipline as represented by ICT, computing and informatics across schools, FE and HE in the UK.

\section{METHODS}

\subsection{Sample}

The survey aimed to investigate how the UK computer science education workforce has viewed the move to online LT\&A. The target population was those who are actively involved in the delivery of LT\&A within the education sector. Those who did not meet this criterion were excluded from analysis post-hoc.

We adopted a convenience sampling approach in distributing the Qualtrics survey whereby a link to the survey was shared via mailing lists of professional networks and related education organisations (for example, via the Council for Professors and Heads of Computing (CPHC), BCS Academy, ACM SIGCSE, the UK's University and College Union (UCU), and the British Educational Research Association (BERA) Higher Education Special Interest Group, in addition to Twitter and LinkedIn). While the use of convenience sampling does not allow generalisation to a representative population, this sampling technique allowed us to document patterns within the observed population, with minimal time and cost restrictions.

After excluding those that did not meet the participant requirements 2,197 members of the UK education workforce responded to the survey. This included 1,148 respondents from the HE (university) sector (52.3\%), 279 respondents from FE (12.7\%) and 569 respondents from schools (25.9\%). 214 participants indicated that they taught computer science. This included 119 from the HE sector (55.6\%), 24 from FE (11.2\%) and 71 from schools (33.2\%).

The survey was launched on 26 March 2020 following the announcement of closures across all educational settings in all four nations of the UK, and remained open for four weeks. Due to the 
distribution method we cannot calculate the response rate; however, of those who started the survey, $84.9 \%$ completed it.

\subsection{Questionnaire}

On the first page of the questionnaire respondents were informed that the research was designed to identify their views and experiences of the move to online LT\&A in response to COVID-19. The first section of the questionnaire consisted of demographic questions in order to determine how participant characteristics impacted key variables. In order to identify those who are computer scientists, those who responded that they worked in the HE sector were asked to select their discipline from a list created using the UK Joint Academic Coding of Subjects (JACS) codes $^{1}$. Those who worked in schools and FE were firstly asked if they taught a particular subject. Those that responded that they did were then asked to select their subject from a list containing all curriculum subjects taught across the four nations of the UK.

Demographic questions were followed by Likert and slider-scale questions exploring respondents' views of the changes. These included questions about how prepared and confident they felt about the move to online teaching. In addition, respondents were asked three open-ended questions in order to gain their overall insight into the impact of the changes: "Please provide any comments of how the online learning and teaching changes brought in as a response to COVID-19 will impact upon" followed by "your role", "your institution" and "your sector of education".

Ethical approval for this study was obtained from Swansea University's College of Arts and Humanities Research Ethics Committee. The survey was piloted on a subsample of the population before distribution to the wider UK computer science workforce.

\subsection{Analysis}

Quantitative bivariate chi-square $\left(\left(\chi^{2}\right)\right)$ analysis of the key variables was conducted in order to determine overall attitudes to online LT\&A and whether there were significant differences between those in computer science and those in other disciplines. Chi-square tests were utilised due to the categorical nature of the variables and to assess whether the observed cell counts are significantly different from the expected cell counts. As there were more participants from computer science that responded from HE institutions it was necessary to control for the effect of setting on these outcomes. Furthermore, it could be hypothesised that variables such as gender and years working in education may have also predict the participants responses to these questions. Therefore, binary logistic regression was used in order to control for these variables.

Qualitative analysis of the open-ended questions used thematic analysis. Thematic analysis has been described as "a method for identifying, analysing and reporting patterns (themes) within data" [3, p.78]. This was done by firstly reading through the qualitative responses and numerically coding the data to identify whether comments were positive, negative or neutral. The responses were coded by two researchers to ensure inter-rater reliability ( $I R R=0.82)$. Within these codes potential themes were identified: "a theme captures something important about the data in relation to the research

\footnotetext{
${ }^{1}$ https://www.hesa.ac.uk/support/documentation/jacs
}

question and represents some level of patterned response or meaning within the data set" [3, p.82]. These themes were reviewed rigorously against the data to ensure that they were compatible with the data and accurately represented the comments.

\section{RESULTS}

\subsection{Quantitative Data}

Figure 1 shows that those who work within the computer science discipline were significantly more likely to say that they felt prepared $\left(\chi^{2}(1)=22.02, \mathrm{p}<0,001\right)$, confident $\left(\chi^{2}(1)=22.98, \mathrm{p}<0,001\right)$, supported by their institution $\left(\chi^{2}(1)=4.5, \mathrm{p}=0.03\right)$, held a good working knowledge of appropriate technologies $\left(\chi^{2}(1)=47.75, \mathrm{p}<0,001\right)$, had access to appropriate technologies $\left(\chi^{2}(1)=13.19, \mathrm{p}<0,001\right)$ and were confident that their students could access online LT\&A $\left(\chi^{2}(1)=\right.$ 17.16, $\mathrm{p}<0,001)$.

Table 1 shows the results from binary regression on each statement. This demonstrates that the impact of working within the computer science discipline remains significant when controlling for setting, gender, and years teaching. It also shows that those in schools were significantly more likely to agree with the statements than those in HE and FE.

\subsection{Qualitative Data}

The qualitative data were coded into positive, negative and neutral responses. Of the 102 computer scientists that commented on the impact on their role 23 (22.6\%) were positive, 54 (52.9\%) were negative and $25(24.5 \%)$ were neutral. 94 computer scientists provided a comment on the impact on their institution, of these $20(21.3 \%)$ were positive, $59(56.7 \%)$ were negative and 15 (15\%) were neutral. Finally, 67 computer scientists commented on the impact on their sector, of these $16(23.9 \%)$ were positive, 36 (53.7\%) were negative and $15(22.4 \%)$ neutral. Key themes were identified within the responses. These will now be discussed in relation to computer sciences education.

\subsubsection{Change as progressive.}

"Computer science education is probably a good place to be right now." [HE]

"We are in a pretty unique place because of what we teach." [school]

Computer scientists mentioned a number of progressive and beneficial aspects to the change to online LT\&A for the discipline. Most prominently, respondents pointed out how the changes have and would lead to more recognition of the importance of technology. Common responses mentioned the "greater staff awareness of educational technologies" [school] and that "everyone hopefully will now appreciate that digital literacy is important" [school]. This led to many respondents also recognising how computer science as a subject may have its profile raised by the mass move to the use of digital technology for learning. One respondent noted "it may put further emphasis on computing as a subject, with so much technology in use" [school]. As a result, respondents foresaw long-term benefits for computer science as a discipline within education "ICT has gone up massively as a valued skill - hopefully a trend that will be reflected and its impact will be increased in terms of curriculum timetabling" [school]. 


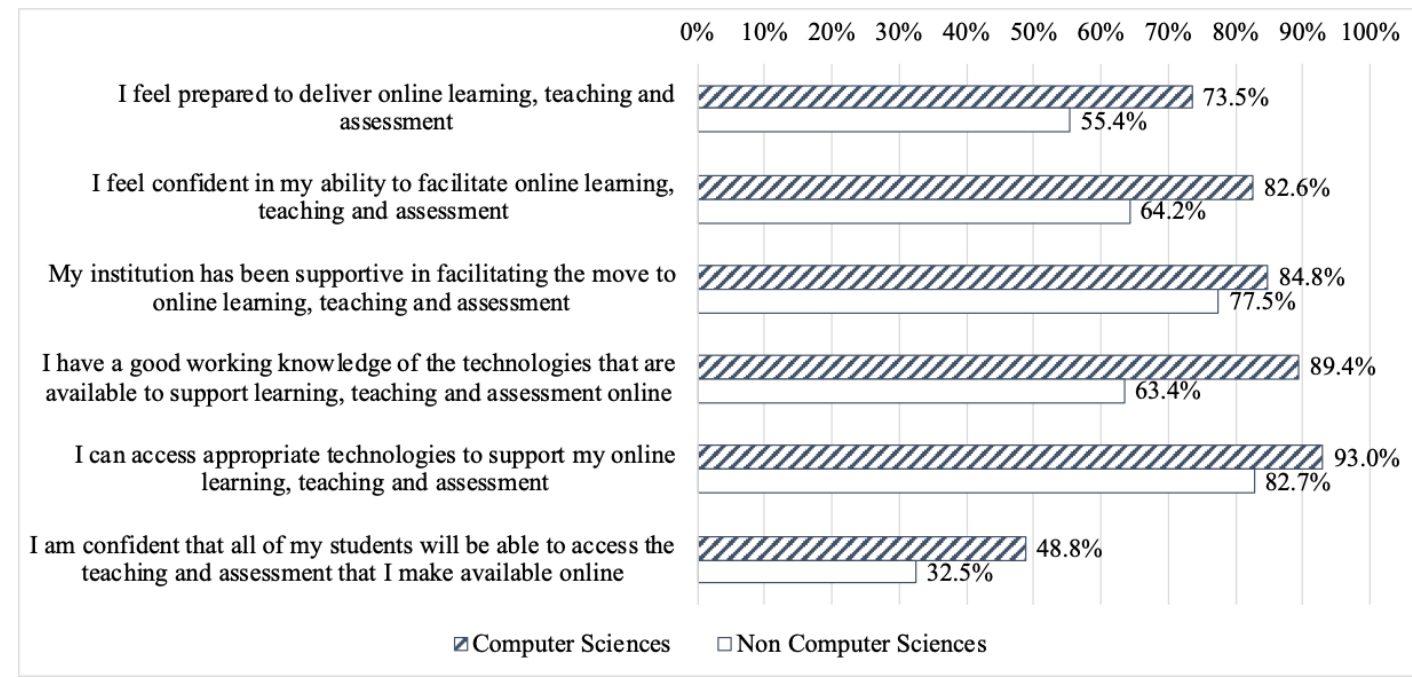

Figure 1: Percentage of participants that agree to statements about online LT\&A

\begin{tabular}{|c|c|c|c|c|c|c|c|c|c|c|c|c|c|c|c|c|c|c|c|c|c|c|c|c|c|}
\hline \multirow[t]{2}{*}{ Variable } & \multirow[t]{2}{*}{ Category } & \multicolumn{4}{|c|}{$\begin{array}{l}\text { "I feel prepared to deliver } \\
\text { online LT\&A" }\end{array}$} & \multicolumn{4}{|c|}{$\begin{array}{l}\text { "I feel confident in my ability } \\
\text { to facilitate online LT\&A" }\end{array}$} & \multicolumn{4}{|c|}{$\begin{array}{l}\text { "My institution has been } \\
\text { supportive in facilitating } \\
\text { the move to online LT\&A" }\end{array}$} & \multicolumn{4}{|c|}{$\begin{array}{l}\text { "I have a good working } \\
\text { knowledge of the technologies } \\
\text { that are available to support } \\
\text { online LT\&A" }\end{array}$} & \multicolumn{4}{|c|}{$\begin{array}{l}\text { "I can access appropriate } \\
\text { technologies to support my } \\
\text { online LT\&A" }\end{array}$} & \multicolumn{4}{|c|}{$\begin{array}{l}\text { "I am confident that all of my } \\
\text { students will be able to access } \\
\text { the teaching and assessment } \\
\text { that I make available online" }\end{array}$} \\
\hline & & $\beta$ & SE & $\mathrm{p}$ & $\begin{array}{l}\text { Odds } \\
\text { Ratio }\end{array}$ & $\beta$ & SE & $\mathrm{p}$ & $\begin{array}{l}\text { Odds } \\
\text { Ratio }\end{array}$ & $\beta$ & SE & $\mathrm{p}$ & $\begin{array}{l}\text { Odds } \\
\text { Ratio }\end{array}$ & $\beta$ & SE & $\mathrm{p}$ & $\begin{array}{l}\text { Odds } \\
\text { Ratio }\end{array}$ & $\beta$ & SE & $\mathrm{p}$ & $\begin{array}{l}\text { Odds } \\
\text { Ratio }\end{array}$ & $\beta$ & SE & $\mathrm{p}$ & $\begin{array}{l}\text { Odds } \\
\text { Ratio }\end{array}$ \\
\hline CS & $\begin{array}{l}\text { Non CS (ref) } \\
\text { CS }\end{array}$ & -0.77 & 0.19 & $<0.001$ & 0.46 & -0.92 & 0.22 & $<0.001$ & 0.4 & -0.7 & 0.14 & 0.04 & 0.61 & -1.59 & 0.27 & $<0.001$ & 0.20 & -0.94 & 0.32 & 0.003 & 0.39 & -0.59 & 0.18 & $<0.001$ & 0.55 \\
\hline Gender & $\begin{array}{l}\text { Male (ref) } \\
\text { Female }\end{array}$ & 0.32 & 0.11 & 0.005 & 1.37 & 0.35 & 0.12 & 0.005 & 1.42 & -0.07 & 0.14 & 0.6 & 0.93 & 0.40 & 0.13 & 0.002 & 1.50 & 0.23 & 0.16 & 0.136 & 1.26 & 0.37 & 0.12 & 0.002 & 1.45 \\
\hline $\begin{array}{l}\text { Years } \\
\text { working }\end{array}$ & $\begin{array}{l}0-5 \text { (ref } \\
6-10 \\
11-15 \\
16-20 \\
21-25 \\
26+\end{array}$ & $\begin{array}{l}-0.12 \\
-0.0 \\
0.06 \\
0.25 \\
0.39\end{array}$ & $\begin{array}{l}0.19 \\
0.18 \\
0.19 \\
0.19 \\
0.19\end{array}$ & $\begin{array}{l}0.53 \\
0.99 \\
0.76 \\
0.18 \\
0.04\end{array}$ & $\begin{array}{l}0.89 \\
0.99 \\
1.06 \\
1.29 \\
1.48\end{array}$ & $\begin{array}{l}-0.29 \\
0.02 \\
0.00 \\
0.20 \\
0.36\end{array}$ & $\begin{array}{l}0.20 \\
0.2 \\
0.2 \\
0.20 \\
0.20\end{array}$ & $\begin{array}{l}0.15 \\
0.89 \\
0.99 \\
0.31 \\
0.08\end{array}$ & $\begin{array}{l}0.75 \\
1.03 \\
1.00 \\
1.22 \\
1.43\end{array}$ & $\begin{array}{l}0.12 \\
0.51 \\
0.47 \\
0.32 \\
0.31\end{array}$ & $\begin{array}{l}0.24 \\
0.22 \\
0.23 \\
0.25 \\
0.24\end{array}$ & $\begin{array}{l}0.61 \\
0.02 \\
0.45 \\
0.19 \\
0.19\end{array}$ & $\begin{array}{l}1.13 \\
1.66 \\
1.60 \\
1.38 \\
1.37\end{array}$ & $\begin{array}{l}-0.01 \\
0.08 \\
0.24 \\
0.47 \\
0.65\end{array}$ & $\begin{array}{l}0.20 \\
0.20 \\
0.21 \\
0.21 \\
0.22\end{array}$ & $\begin{array}{l}0.98 \\
0.68 \\
0.26 \\
0.02 \\
0.003\end{array}$ & $\begin{array}{l}1.00 \\
1.08 \\
1.27 \\
1.60 \\
1.91\end{array}$ & $\begin{array}{l}0.22 \\
0.29 \\
0.31 \\
0.73 \\
0.20\end{array}$ & $\begin{array}{l}0.26 \\
0.25 \\
0.26 \\
0.25 \\
0.28\end{array}$ & $\begin{array}{l}0.4 \\
0.25 \\
0.24 \\
0.01 \\
0.50\end{array}$ & $\begin{array}{l}1.24 \\
1.33 \\
1.36 \\
2.08 \\
1.22\end{array}$ & $\begin{array}{l}0.01 \\
0.06 \\
0.04 \\
-0.03 \\
0.00\end{array}$ & $\begin{array}{l}0.20 \\
0.19 \\
0.20 \\
0.20 \\
0.20\end{array}$ & $\begin{array}{l}0.981 \\
0.759 \\
0.829 \\
0.865 \\
0.997\end{array}$ & $\begin{array}{l}1.01 \\
1.06 \\
1.04 \\
0.97 \\
1.00\end{array}$ \\
\hline Setting & $\begin{array}{l}\text { School (ref) } \\
\text { FE } \\
\text { HE }\end{array}$ & $\begin{array}{l}0.67 \\
1.08\end{array}$ & $\begin{array}{l}1.78 \\
0.11\end{array}$ & $\begin{array}{l}<0.001 \\
<0.001\end{array}$ & $\begin{array}{l}1.96 \\
2.94\end{array}$ & $\begin{array}{l}0.76 \\
0.94\end{array}$ & $\begin{array}{l}0.19 \\
0.14\end{array}$ & $\begin{array}{l}<0.001 \\
<0.001\end{array}$ & $\begin{array}{l}2.14 \\
2.55\end{array}$ & $\begin{array}{l}0.61 \\
1.07\end{array}$ & $\begin{array}{l}0.24 \\
0.24\end{array}$ & $\begin{array}{l}0.01 \\
<0.001\end{array}$ & $\begin{array}{l}1.84 \\
2.92\end{array}$ & $\begin{array}{l}0.85 \\
1.14\end{array}$ & $\begin{array}{l}0.20 \\
0.15\end{array}$ & $\begin{array}{l}<0.001 \\
<0.01\end{array}$ & $\begin{array}{l}2.35 \\
3.11\end{array}$ & $\begin{array}{l}0.70 \\
0.78\end{array}$ & $\begin{array}{l}0.24 \\
0.19\end{array}$ & $\begin{array}{l}0.004 \\
<0.001\end{array}$ & $\begin{array}{l}2.01 \\
2.18\end{array}$ & $\begin{array}{l}-0.23 \\
-0.56\end{array}$ & $\begin{array}{l}0.19 \\
0.14\end{array}$ & $\begin{array}{l}0.235 \\
<0.001\end{array}$ & $\begin{array}{l}0.80 \\
0.57\end{array}$ \\
\hline Constan & & -1.29 & 0.19 & $<0.001$ & 0.28 & -1.55 & 0.20 & $<0.001$ & 0.21 & -2.29 & 0.25 & $<0.001$ & 0.10 & -1.86 & 0.22 & $<0.001$ & 0.16 & -2.65 & 0.27 & $<0.001$ & 0.07 & 0.82 & 0.19 & $<0.001$ & 2.26 \\
\hline
\end{tabular}

Table 1: Binary regressions on key survey statements

"If used and set up well, it could be amazing. Breaking down barriers to edtech and embracing technology for a connected student experience" [school]

Further opportunities were noted in the advance in educational digital infrastructure. A key theme was the acknowledgement of the "range, quality and resilience of key digital infrastructure and tools" [HE] and how it may "open new opportunities to try new online tools" [school]. Furthermore, respondents mentioned the potential positive impact of financial investment in digital infrastructure. This was coupled with discussion of the opportunities for professional development in the area of online LT\&A. It was recognised that there had been "more ongoing support for staff with technology" [school] and this would lead to long term benefits:

"It will involve a forced skills upskilling in IT skills for a number of older members of staff. [...] Once over the initial hurdle, I feel this could be of benefit long term. But this has only happened due to significant support made available to them to support this" [school]

There was also discussion about the positive impact this could have on pedagogy and practice as it has "opened opportunities for flexible learning" [school]. Furthermore, respondents mentioned that "it will allow the department to be creative and be innovative in the way lessons are presented to students" [school]; therefore, indicating potentially innovation online LT\&A methods for computer science education.

There was also acknowledgement that while there may be difficulties in terms of equity of access "computer science will be one of the least hit as our colleagues and students are among the most capable when it comes to operating online" [HE].

\subsubsection{Change as challenge.}

"I am concerned that my institution thinks a move online is a move to more innovative and 
modern teaching, just by virtue of it being online.” [HE]

"HE will move increasingly to online provision, sadly. Our technologies do not currently allow the creation and manipulation of shared mental representations which is necessary for effective teaching and learning of mathematics and computer science." [HE]

While acknowledgement of opportunities was clear within the qualitative data, respondents also raised concerns about the impact of the move to online LT\&A. A key theme within these concerns was whether the move to online LT\&A would be as pedagogically beneficial to the students as face to face teaching. The quote above summarise the concern that top-down messages from institutions imply that 'good practice is online', however, there is concern that these decisions are not pedagogically-driven. A number of respondents raised concerns that computer science is "skills-based rather than fact-based. I long ago abandoned the traditional lecture as being inappropriate for teaching [...]. Too often, moving teaching online means moving back to more traditional teaching styles." [HE] and that "teaching programming techniques and complex concepts of computer science online is difficult" [school]. Furthermore, while respondents were aware of the negative impact of the lack of face-to-face teaching on teaching computer science, they also acknowledged that "social interaction is arguably an important component of the student experience" [HE]. Thus, suggesting wider pedagogical issues due to the lack of face-to-face teaching.

Along with a perceived negative impact on effective pedagogy due to the move to online LT\&A, concerns were also raised about the equity of access to the necessary resources for learning: "online learning in CS is heavily dependent on pupils' home access" [school]. Furthermore, concern was raised about the lack of access to labs and computer science specific software for LT\&A: "access to specialist laboratories and equipment has been curtailed. Depending upon a student's specialism within computer science their experience could be more significantly affected. For example, those studying networking or robotics" [HE].

Also, while respondents acknowledged the lack of necessary physical resource as a problem for their students, many acknowledged the lack of their own time as a key concern: "the main problem is not availability of resource and support, but the time needed to acquire skills in using them, for which there is no space in my current role" [HE]. The impact of moving resources online on workload was a concern raised across the discipline: "huge uncertainty, possibly spending all summer converting a large course to online without knowing whether/if students will even enrol" [HE]. This concern about the fragility of the sector was particularly prominent in respondents from HE. This was reinforced by concerns across all sectors for the health and wellbeing of both practitioners and students, linking back to previous comments regarding equity and personal circumstances: "It makes me want to get out of teaching computing; the amount of time that I spend at the computer feels tiresome at the best of times, and now that there is no face-to-face contact with students, the computer time is very demoralising" [school] and "My role is shifting towards advising and away from teaching. A major challenge will be students' mental health, not their ability to write fava code." [HE].

\section{DISCUSSION}

"This is the beginning of a new era. Things will never be the same again." [HE]

"Computer Science will boom." [HE]

\subsection{Key Themes}

The quantitative data demonstrates that in the immediate aftermath of the rapid move to online LT\&A, those working in computer science perceived themselves as being significantly more prepared, confident, held a good working knowledge of the relevant technologies and felt supported by their institution than those in other disciplines. Furthermore, they were significantly more likely to agree that both themselves and their students could access the online LT\&A. While those in secondary schools were significantly more likely to agree with these statements than those in FE and $\mathrm{HE}$, being a computer scientist remained a significant predictor of these viewpoints when controlling for setting, gender, and years working in the profession. These results are, perhaps, unsurprising, given the likely proficiency of computer scientists to use technology. However, they highlight that this confidence with technology translates to its use for online LT\&A.

"As a Computing teacher, most of my resources are already online. However, teaching programming techniques and complex concepts of computer science online is difficult." [school]

Central to both the positive and negative commentary was the theme of pedagogy. While some recognised the potential that moving teaching online could allow practitioners to be 'flexible' and 'creative' with their pedagogy, practitioners expressed concern about how key foundation topics and threshold concepts in computer science can be taught effectively without face-to-face instruction. Therefore, while some literature has demonstrated the use of technology to enhance teaching, a number of practitioners were concerned about its place in computer science education, especially for key topics in computer science, such as programming and mathematical foundations, as well as more practical or collaborative topics such as robotics and group software projects.

\section{"Specifically I work in an area that involves some hands on practical projects. These cannot be rep- licated online, so the student experience will be significantly changed." [HE]}

Yet, it could also be argued that the efficiency of online teaching may be overplayed by institutions. This may be particularly true of the HE sector who may be rapidly moving teaching online, without the necessary workforce development and understanding of effective online pedagogy. As noted in the responses, there may be longer term positive impact of this technological upskilling of the education workforce, however, significant concerns were raised about the impact on workload due to these changes. There were also concerns raised about top-down, "one size fits all" institutional approaches, rather than evaluating and addressing disciplinary-specific challenges and supporting appropriate pedagogic approaches. 
Another theme that was acknowledged as both a challenge and an opportunity was the impact on educational digital infrastructure. While practitioners acknowledged the potential opportunities of institutional financial investment in digital infrastructure, concern was raised about equity of access to these recourses. While it was acknowledged that computer science students may be the least affected by this in HE, there was concern for those that could not access appropriate technologies at home. Specifically, a lack of access to specialist labs or software may be an issue going forward.

"I teach programming and robotics. Programming transitions easily to online learning but Robotics does not. It remains to be seen if we can continue that class." [HE]

\subsection{Limitations}

It is also necessary to note limitations of this research and to highlight potential for future research in this area. Firstly, this study has grouped together UK computer science practitioners from across various educational settings. It could be argued that the difference in experience of these practitioners is vast and, consequently, it is difficult to recognise them as a homogenous group. However, logistic regression analysis demonstrated that even while controlling for setting, identifying as a computer scientist was a significant predictor of responses to the key statements. Across all participants, secondary school practitioners were significantly more positive than those in HE and FE. Therefore, future research should investigate why this trend has been identified, and whether those in HE and FE can learn from practitioners in schools about effective methods of online LT\&A.

Secondly, as this research was conducted in the immediate aftermath of the move to online LT\&A it could be argued that, due to the rapid changes in the situation since March 2020, attitudes may have changed since this data was collected. However, this research offers insight into the education workforce's perceptions during these radical changes to their practices. The results highlight the longer-term opportunities and challenges that the move may bring about. Furthermore, follow up research should be conducted in order to understand whether perceptions have changed since this data was collected.

\section{CONCLUSIONS AND LOOKING AHEAD}

Many of the challenges and opportunities presented by COVID-19 and the rapid shift to "emergency remote teaching" as identified in this survey could be applied more broadly across the various educational settings in the UK. In particular, there are significant concerns regarding impact on jobs, career progression, financial sustainability of institutions [49], robustness of the qualifications and examinations system, issues of equity and access to technology, as well as the health and wellbeing of practitioners and students ${ }^{2}$. It is also important to acknowledge the ongoing media narrative regarding online teaching being perceived as lower quality than face-to-face teaching (especially for HE) [10, 36]; however, teaching

\footnotetext{
${ }^{2}$ Also see: "Academic lives are in transition" https://wonkhe.com/blogs academic-lives-are-in-transition/ (May 2020) and "Forced shift to online teaching in coronavirus pandemic unleashes educators' deepest job fears" https://www.natureindex.com/news-blog/forced-shift-to-online-teaching-incoronavirus-pandemic-unleashes-educators-deepest-job-fears- (April 2020)
}

quality is more important than how lessons are delivered [23], while technology can be used to improve the quality of explanations and modelling, and can play a role in improving assessment and feedback [22].

The rapid adoption of digital technologies for almost all activities that could previously have taken place within the physical space of an educational institution presents opportunities to rethink how many academic practices might take place in virtual environments. These resultant shifts in culture, identity, and new demands on educational leadership and management [25], perhaps reshaping the post-pandemic digital structure of education, also risk exacerbating existing inequalities in the use of digital technologies and opening up new areas of academic life to surveillance and control [5].

However, there are a number of specific issues for UK computer science practitioners that provides valuable insight and context for the discipline as we move with some uncertainty towards the next academic year and beyond. In particular, the increased prominence of technology in an educational context provides opportunities for showcasing the importance of cross-curricular digital and data skills, as well as the explicit value of computer science as a STEM academic discipline. This clearly resonates with recent curricula and qualifications reform across the four nations of the UK, especially as computer science is starting to become more established as a school-level subject $[2,4,15,32]$. There is also an increasing focus on identifying and refining effective pedagogic approaches for LT\&A on key topics in computer science, such as mathematical foundations, programming and cybersecurity [13, 14, 16, 18, 34, 37, 42]. However, there are concerns of top-down, "one-size-fits-all" institutional or national approaches that do not recognise the unique characteristics of LT\&A in computer science across the various settings and levels. Further work is required to identify and share best practice for some of these challenges, especially with regards to assessment, certification and qualifications. Moving from the specific computer science education and skills context to the wider IT industry and UK digital economy focus, it is clear there will be a huge demand for digital skills and infrastructure [17, 45]. to support the UK's post-COVID economic renewal [33]. We have also seen the announcement of a review of academic accreditation of computer science degrees $[12,14]$ launched at the start of July, to "ensure that computing graduates have the skills needed to drive economic recovery as data science and AI change the industry post COVID-19"3.

Finally, recent evidence suggests that young people are more interested in science and technology careers as a result of COVID- $19^{4}$, alongside opportunities to promote cross-curricula and interdisciplinary approaches in school STEM lessons when addressing wider societal issues [40]. Based on the data obtained from this rapid response survey of UK computer science practitioners, we anticipate continued evaluation and development of best practice for online LT\&A as we move into the 2020-2021 academic year and beyond, especially as it appears that the virus may have to be tolerated on an indefinite basis [27].

\footnotetext{
${ }^{3}$ See: $\quad$ https://www.bcs.org/more/about-us/press-office/press-releases/review-ofacademic-accreditation-of-computer-science-degrees-launched/

${ }^{4}$ See: https://www.britishscienceassociation.org/blog/young-people-are-moreinterested-in-a-scientific- career-as-a-result-of-covid-19
} 


\section{REFERENCES}

[1] Richard Armitage and Laura B. Nellums. 2020. Considering inequalities in the school closure response to COVID-19. The Lancet Global Health 8, 5 (2020), E644. https://doi.org/10.1016/S2214-109X(20)30116-9

[2] Stuart Arthur, Tom Crick, and Janet Hayward. 2013. The ICT Steering Group's Report to the Welsh Government. https://gov.wales/future-computer-scienceand-information-technology-schools-ict-steering-group-report.

[3] Virginia Braun and Victoria Clarke. 2006. Using thematic analysis in psychology. Qualitative Research in Psychology 3, 2 (2006), 77-101. https://doi.org/10.1191/ 1478088706qp063oa

[4] Neil C. C. Brown, Sue Sentance, Tom Crick, and Simon Humphreys. 2014. Restart The Resurgence of Computer Science in UK Schools. ACM Transactions on Computer Science Education 14, 2 (2014), 1-22. https://doi.org/10.1145/2602484

[5] Mark Carrigan. 2020. Are we all digital scholars now? How the lockdown will reshape the post-pandemic digital structure of academia. https://blogs.lse.ac.uk/ impactofsocialsciences/2020/04/10/are-we-all-digital-scholars-now-how-thelockdown-will-reshape-the-post-pandemic-digital-structure-of-academia/.

[6] Rory Cellan-Jones. 2020. Coronavirus: What went wrong with the UK's contact tracing app? https://www.bbc.co.uk/news/technology-53114251. BBC News.

[7] Vinton G. Cerf. 2020. Implications of the COVID-19 pandemic. Communications of the ACM 63, 6 (2020). https://doi.org/10.1145/3397262

[8] Soon Ae Chun, Alen Chih Yuan Li, Alen Chih-Yuan Li, Amir Toliyat, and James Geller. 2020. Tracking Citizen's Concerns during COVID-19 Pandemic. In Proc. 21st Annual International Conference on Digital Government Research. ACM. https://doi.org/10.1145/3396956.3397000

[9] Johannes Conrads, Morten Rasmussen, Niall Winters, Anne Geniet, and Laurenz Langer. 2017. Digital Education Policies in Europe and Beyond: Key Design Principles for More Effective Policies. . European Commission, Joint Research Centre.

[10] Sean Coughlan. 2020. Students 'must be warned if courses taught online'. https: //www.bbc.co.uk/news/education-52709516. BBC News.

[11] Tom Crick. 2017. After the Reboot - Computing Education in UK Schools. Royal Society, Chapter Computing Education: An Overview of Research in the Field. https://royalsociety.org/topics-policy/projects/computing-education/.

[12] Tom Crick, James H. Davenport, Paul Hanna, Alastair Irons, and Tom Prickett. 2020. Computer Science Degree Accreditation in the UK: A Post-Shadbolt Review Update. In Proc. Computing Education Practice. Article 6. https://doi.org/10.1145/ 3372356.3372362

[13] Tom Crick, James H. Davenport, Paul Hanna, Alastair Irons, and Tom Prickett. 2020. Overcoming the Challenges of Teaching Cybersecurity in UK Computer Science Degree Programmes. In Proc. 50th Annual Frontiers in Education Conference (FIE 2020).

[14] Tom Crick, James H. Davenport, Alastair Irons, and Tom Prickett. 2019. A UK Case Study on Cybersecurity Education and Accreditation. In Proc. 49th Annual Frontiers in Education Conference (FIE 2019). 1-9. https://doi.org/10.1109/ FIE43999.2019.9028407

[15] Tom Crick and Sue Sentance. 2011. Computing At School: Stimulating Computing Education in the UK. In Proc. 11th Koli Calling International Conference on Computing Education Research. ACM. https://doi.org/10.1145/2094131.2094158

[16] James H. Davenport and Tom Crick. 2019. Cybersecurity Education and Formal Methods. In Proc. 1st Int. Workshop "Formal Methods-Fun for Everybody".

[17] James H. Davenport, Tom Crick, and Rachid Hourizi. 2020. The Institute of Coding: A University-Industry Collaboration to Address the UK's Digital Skills Crisis. In Proc. IEEE Global Engineering Education Conference (EDUCON2020). 1400-1408. https://doi.org/10.1109/EDUCON45650.2020.9125272

[18] James H. Davenport, Alan Hayes, Rachid Hourizi, and Tom Crick. 2016. Innovative Pedagogical Practices in the Craft of Computing. In Proc. 4th International Conference on Learning and Teaching in Computing and Engineering (LaTiCE 2016). https://doi.org/10.1109/LaTiCE.2016.38

[19] Department for Education. 2019. Realising the potential of technology in education A strategy for education providers and the technology industry. UK Government.

[20] Armand Doucet, Deborah Netolicky, Koen Timmers, and Francis Jim Tuscano. 2020. Thinking about Pedagogy in an Unfolding Pandemic: An Independent Report on Approaches to Distance Learning During COVID19 School Closures.

[21] Yogesh Dwivedi, Laurie Hughes, Elvira Ismagilova, Gert Aarts, Crispin Coombs, and Tom Crick et al. 2019. Artificial Intelligence (AI): Multidisciplinary Perspectives on Emerging Challenges, Opportunities, and Agenda for Research, Practice and Policy. International fournal of Information Management (2019). https://doi.org/10.1016/j.ijinfomgt.2019.08.002

[22] EEF. 2019. Using Digital Technology to Improve Learning. Education Endowment Foundation. https://educationendowmentfoundation.org.uk/tools/guidancereports/using-digital-technology-to-improve-learning/.

[23] EEF. 2020. Remote Learning: Rapid Evidence Assessment. Education Endowment Foundation. https://educationendowmentfoundation.org.uk/covid-19resources/best-evidence-on-supporting-students-to-learn-remotely/.

[24] Richard E. Ferdig, Emily Baumgartner, Richard Hartshorne, Regina KaplanRakowski, and Chrystalla Mouza. 2020. Teaching, Technology, and Teacher Education during the COVID-19 Pandemic: Stories from the Field. Association for the
Advancement of Computing in Education (AACE)

[25] Alma Harris, Michelle Jones, and Tom Crick. 2020. Teacher Leadership Revisited: The Case for Curriculum Leadership. School Leadership \& Management 40, 1 (2020), 1-4. https://doi.org/10.1080/13632434.2020.1704470

[26] Jisc. 2020. Learning and teaching reimagined: Change and challenge for students, staff and leaders. https://www.jisc.ac.uk/reports/learning-and-teachingreimagined-change-and-challenge.

[27] Stephen M. Kissler, Christine Tedijanto, Edward Goldstein, Yonatan H. Grad, and Marc Lipsitch. 2020. Projecting the transmission dynamics of SARS-CoV-2 through the postpandemic period. Science 368, 6493 (2020), 860-868.

[28] Rosemary Luckin, Brett Bligh, Andrew Manches, Shaaron Ainsworth, Charles Crook, and Richard Noss. 2012. Decoding Learning: The Proof, Promise and Potential of Digital Education. Nesta. https://www.nesta.org.uk/report/decodinglearning/.

[29] Richard E. Mayer. 2018. Thirty years of research on online learning. Applied Cognitive Psychology 33, 2 (2018), 152-159. https://doi.org/10.1002/acp.3482

[30] Barbara Means. 2014. Learning Online: What Research Tells Us About Whether, When and How. Routlege. ISBN: 978-0415630290.

[31] Microsoft Research. 2020. Impact of COVID-19 on the Computer Science Research Community. https:/www.microsoft.com/en-us/research/project/academic/ articles/impact-of-covid-19-on-computer-science-research-community/.

[32] Faron Moller and Tom Crick. 2018. A University-Based Model for Supporting Computer Science Curriculum Reform. Fournal of Computers in Education 5, 4 (2018), 415-434. https://doi.org/10.1007/s40692-018-0117-x

[33] Oliver Dowden MP. 2020. Digital Secretary's closing speech to the UK Tech Cluster Group. https://www.gov.uk/government/speeches/digital-secretarysclosing-speech-to-the-uk-tech-cluster-group. UK Government.

[34] Ellen Murphy, Tom Crick, and James H. Davenport. 2017. An Analysis of Introductory Programming Courses at UK Universities. The Art, Science, and Engineering of Programming 1(2), 18 (2017). https://doi.org/10.22152/programmingjournal.org/2017/1/18

[35] OECD. 2020. Science in the face of the COVID-19 crisis. https:// oecdsciencesurveys.github.io/2020flashsciencecovid/.

[36] Manuela Paechter and Brigitte Maier. 2010. Online or face-to-face? Students' experiences and preferences in e-learning. The Internet and Higher Education 13, 4 (2010), 292-297. https://doi.org/10.1016/j.iheduc.2010.09.004

[37] Tom Prickett, Morgan Harvey, Julie Walters, Longzhi Yang, and Tom Crick. 2020. Resilience and Effective Learning in First-Year Undergraduate Computer Science. In Proc. 25th Annual Conference on Innovation and Technology in Computer Science Education (ITiCSE 2020). https://doi.org/10.1145/3341525.3387372

[38] QAA. 2020. Building a Taxonomy for Digital Learning. https://www.qaa.ac.uk/ docs/qaa/guidance/building-a-taxonomy-for-digital-learning.pdf.

[39] Fernando M. Reimer and Andreas Schleiche. 2020. A framework to guide an education response to the COVID-19 Pandemic of 2020. OECD.

[40] Michael J. Reiss. 2020. Science Education in the Light of COVID-19. Science \& Education (2020). https://doi.org/10.1007/s11191-020-00143-5

[41] Scottish Government. 2020. Enhancing learning and teaching through the use of digital technology: A digital learning and teaching strategy for Scotland. Learning Directorate, Scottish Government. https://www.gov.scot/publications/ enhancing-learning-teaching-through-use-digital-technology/.

[42] Simon, Raina Mason, Tom Crick, James H. Davenport, and Ellen Murphy. 2018. Language Choice in Introductory Programming Courses at Australasian and UK Universities. In Proc. 49th ACM Technical Symposium on Computer Science Education (SIGCSE 2018). ACM, 852-857. https://doi.org/10.1145/3159450.3159547

[43] The Lancet. 2020. Editorial: Redefining vulnerability in the era of COVID-19. The Lancet 395 (2020). https://doi.org/10.1016/S0140-6736(20)30757-1

[44] Daniel Shu Wei Ting, Lawrence Carin, Victor Dzau, and Tien Y. Wong. 2020. Digital technology and COVID-19. Nature Medicine 26 (2020), 459-461. https: //doi.org/10.1038/s41591-020-0824-5

[45] Theo Tryfonas and Tom Crick. 2018. Public Policy and Skills for Smart Cities: The UK Outlook. In Proc. 11th International Conference on PErvasive Technologies Related to Assistive Environments (PETRA'18). ACM, 116-117. https://doi.org/ $10.1145 / 3197768.3203170$

[46] UNESCO. 2020. COVID-19 Impact on Education. https://en.unesco.org/covid19/ educationresponse.

[47] Wim Van Lancker and Zachary Parolin. 2020. COVID-19, school closures, and child poverty: a social crisis in the making. The Lancet Public Health 5, 5 (2020), E243-E244. https://doi.org/10.1016/S2468-2667(20)30084-0

[48] Joachim von Braun, Stefano Zamagni, and Marcelo Sánchez Sorondo. 2020. The moment to see the poor. Science 368, 6488 (2020). https://doi.org/10.1126/ science.abc 2255

[49] Richard Watermeyer, Tom Crick, Cathryn Knight, and Janet Goodall. 2020. COVID-19 and digital disruption in UK universities: afflictions and affordances of emergency online migration. Higher Education (2020). https://doi.org/10.1007/ s10734-020-00561-y

[50] Welsh Government. 2018. Digital Competence Framework guidance. https: //hwb.gov.wales/curriculum-for-wales/cross-curricular-skills-frameworks/. 